\title{
Screening of Natural Compounds With Antimicrobial Activity Against Biofilm-Forming Bacteria Isolated From Bioethanol Production Plants
}

\author{
Rachel Tereza Rigotti (I), Natalia Janaina Lago (I), Renata \\ Athanasio Silva (I), Bruna Lange (I), Renata Ernlud Freitas de \\ Macedo (I), Fernando Bittencourt Luciano (I) \\ (I) PUC PR - Pontifícia Universidade Católica do Paraná (BR 376 Km 14, São José dos Pinhais, \\ PR, Brazil 83010-500)
}

\section{Resumo}

Bacterial contamination during the fermentation of sugarcane wort may significantly reduce the sugar-to-ethanol conversion rate. These microorganisms consume sugars that suppose to be converted in ethanol, and produce substances that inhibit the growth of fermenting yeast. Two of the most prevalent contaminant species in Brazil are Lactobacillus fermentum and Leuconostoc mesenteroides. Both species are able to form biofilm, and therefore, may generate permanent contamination of the wort through their attachment on pipes and fermentation tanks. Antibiotics, such as penicillin, virginiamycin and sodium monensin are currently used to control this bacterial contamination. The objective of this study was to determine the minimum inhibitory concentration (MIC) of natural antimicrobials alone and in combination with sodium dodecyl sulfate against Lactobacillus fermentum and Leuconostoc mesenteroides. The MIC of the natural antimicrobials (ricin oil, cinnamaldehyde, carvacrol, geraniol and allyl isothiocyanate) and sodium dodecyl sulfate (SDS) was determined in tubes containing supplemented sugarcane broth (CSN). Tubes received a $10^{6} \mathrm{CFU} / \mathrm{mL}$ inoculum of either L. fermentum or L. mesenteroides at midexponential phase, and were treated with different doses of the antimicrobials. Tubes were incubated at $200 \mathrm{rpm}, 37^{\circ} \mathrm{C}$ for $24 \mathrm{~h}$. The MIC was considered as the lowest dose of the antimicrobial where there was no

\footnotetext{
Referência:

Rachel Tereza Rigotti, Natalia Janaina Lago, Renata Athanasio Silva, Bruna Lange, Renata Ernlud Freitas de Macedo, Fernando Bittencourt Luciano. Screening of Natural Compounds With Antimicrobial Activity Against Biofilm-Forming Bacteria Isolated From Bioethanol Production Plants. In: Anais do 12을 Congresso Latinoamericano de Microbiologia e Higiene de Alimentos - MICROAL 2014 [= Blucher Food Science Proceedings, num.1, vol.1]. São Paulo: Editora Blucher, 2014. 
increment in the broth optical density. The ricin oil presented a MIC of 2000 ppm, carvacrol 1000 ppm, geraniol 500 ppm, cinnamaldehyde 400 ppm, allyl isothiocayanate $60 \mathrm{ppm}$ and SDS $300 \mathrm{ppm}$. The essential oils with best antimicrobial activity (allyl isothiocyanate and cinnamaldehyde) were evaluated in combination with SDS. Both oils showed synergism with the surfactant, presenting MICs of $15 \mathrm{ppm}$ allyl isothiocyanate $+37,5 \mathrm{ppm}$ SDS and 100 ppm cinnamaldehyde $+37,5$ ppm SDS. This study has shown that allyl isothiocyanate and cinnamaldehyde have the potential to be used in combination with SDS to eliminate planktonic cells of L. mesenteroides e L. fermentum. To our knowledge, this was the first time that the synergism among these substances was described. Further studies will evaluate the use of these compounds in combination against bacterial biofilms.

Palavras-Chave: Natural antimicrobials, Sodium dodecyl sulfate, Biofilmforming bacteria, Contamination

\section{Agência de Fomento:}

